Workers of pedagogical and agricultural institutes, workers of the regional department of public education, the institute of teacher training as well as the best teachers of pedagogical schools and teachers of schools in the city were among the lecturers.

Key words: postgraduate education, retraining, pedagogical workers of preschool education institutions, institute of improving teacher training, forms of advanced training.

Дата надходження статті: 14.122020 . Рецензент: доктор педагогічних наук, професор Данилюк С. С.

У,ДК 373.3.091.12"195"

DOI https://doi.org/10.37915/pa.vi47.179

Шугай Я. М.*, orcid.org/0000-0002-2325-6303

Аупінович С. М.*, orcid.org/0000-0002-6185-470X

\title{
ВИХОВНА ДІЯЛЬНІСТЬ УЧИТЕЛЯ ПОЧАТКОВИХ КЛАСІВ (50-ТІ РР. ХХ СТ.)
}

Статтю присвячено актуальній темі сучасної освіти, а саме виховній діяльності учителя початкових класів у 50-х рр. ХХ $\mathrm{cm}$.

Проаналізовано основні вектори розвитку освіти в Україні, зокрема початкової, иляхом вивчення першоджерел окресленого часового проміжку. 3'ясовано, що в той час в Україні освіта в глобальному значенні та вчителі початкових класів були одними з важливих важелів управління людською свідомістю та становлення світогляду майбутніх будівників комунізму. Визначено, що однією з умов переходу від соціалізму до комунізму досліджуваного періоду вважалося культурне зростання суспільства та забезпечення всебічного розвитку всіх членів громади, їхніх розумових і фізичних здібностей. Однак, поряд з оволодіванням основами наук, перед державою постало завдання забезпечення політехнічної підготовки молоді та виховання їі в дусі комуністичної моралі, розвиток фізичних та художніх нахилів.

Розкрито основні напрями виховної діяльності вчителя початкової школи з молодиими школярами (фізичне, естетичне, трудове виховання). Акцентовано, щцо широкого розповсюдження набула робота з батьківським колективом та співпрацяя з комсомольськими та піонерськими організаціяли. Відзначено активне залучення до освітнього процесу дітей з особливими освітніми потребами та обов'язкове врахування індивідуальних особливостей дітей при плануванні виховної діяльності.

Зроблено висновки, що напруженість та відповідальність в роботі вчителя початкових класів була надзвичайно високою. Адже, крім основної діяльності в школі, вчитель мав забезпечити та урізноманітнити заняття зі школярами в позанавчальний час. Такий темп роботи значно зменшував ефективність роботи вчителя та емоційну причетність до виховної діяльності.

Ключові слова: вчитель початкових класів, початкова школа, напрями виховання, післявоєнний час, організація учнів, робота з батьками, напрями виховання.

Постановка проблеми. Однією з ключових компетентностей Нової української школи за вимогами Державного стандарту початкової освіти є навчання впродовж всього життя. Адже цей аспект є безумовно актуальним на сучасному етапі перебудови української освіти та інтеграції до європейської освітянської спільноти.

Зміст зазначеної компетентності зосереджено на таких ключових моментах, як «здатність до пошуку та засвоєння нових знань, набуття нових вмінь і навичок,

*(C) Шугай Я. М.

“(С) Лупінович С. М.

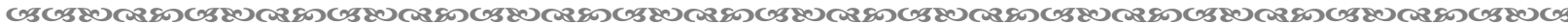


організації навчального процесу (власного і колективного), зокрема через ефективне керування ресурсами та інформаційними потоками, вміння визначати навчальні цілі та способи їх досягнення, вибудовувати свою освітньо-професійну траєкторію, оцінювати власні результати навчання, навчатися впродовж життя» [6, с. 11].

Реалізація буде відбуватися шияхом впровадження інноваційних компонентів в освітній процес, активного залучення батьківської спільноти до життя школи та класу, підтримки й наставництва класного керівника. Реформа Нової української школи офіційно розпочалась від 1 вересня 2018 року 3 трансформації найпершої освітньої ианки - початкової освіти.

Аналіз досліджень. Важко уявити сучасні початкові класи без активних, креативних та енергійних учителів, які відіграють важливу роль у житті кожної людини. Адже на вчителя покладається надзвичайна відповідальність за становлення дитини як особистості, прищеплення любові до пізнання навколишнього світу, виховання патріота своєї країни тощо. Питання виховної діяльності вчителів у освітніх закладах України висвітлювалися в роботах Н. Бахмат [1], Є. Бачинської, О. Кірдан [4], І. Мирної, О. Шквир [7]. Однак, дещо поза увагою науковців задишилося питання організації виховної діяльності вчителів початкових класів у історико-педагогічному дискурсі.

Мета статті - проаналізувати особливості виховної діяльності вчителів початкових класів у 50-х рр. XX ст.

Виклад основного матеріалу. 50-ті pp. XX ст. відзначилися новим реформаторським етапом у сфері освіти у зв'язку з відбудуванням та розширенням мережі загальноосвітніх навчальних закладів у післявоєнний час. Цей період «ознаменувався розширенням та впорядкуванням мережі шкіл. У зв'язку з переходом до обов'язкової семирічної освіти відкривалися нові початкові, семирічні і середні школи, а також початкові школи реорганізовувалися в семирічні, а семирічні в середні» [8, с. 144]. По всій країні закривалися малокомплектні школи, що призвело до певних труднощів як учнів, так і вчителів невеликих сільських шкіл. На вчителя освітнього закладу, а особливо на вчителя початкової школи покладалась велика відповідальність та обов' язки. Як зазначає М. Мельников, годовні задачі, які стоди тоді перед радянською школою, полягали насамперед у такому:

- у підготовці висококваліфікованих будівників комунізму;

- вихованні молодого покоління в дусі комуністичної моралі та життедайного патріотизму;

- прищепленні мододі ненависті до всього старого, віджилого та відданості новому, передовому, прогресивному досвіду;

- вихованні та формуванні в учнях чесності, сміливості, сили волі та твердості характеру, життерадісності, готовності долати будь-які труднощі, захищати честь та незалежність країни [5, с. 17].

Учитель мав безумовний вплив та авторитет, адже результати роботи школи, якість знань учнів залежать від підготовки вчителя, його педагогічної майстерності та особистих якостей [там само, с. 22].

Так, у посібнику для класних керівників середніх шкіл Н. Болдирев визначив основні розділи в діяльності класного керівника, а саме:

- усебічне вивчення класним керівником учнів свого класу;

- організація учнів класу у дружній, об'єднаний колектив;

- проведення заходів 3 підвищення успішності та зміцнення дисципліни учнів;

- щоденна допомога піонерським та комсомодьським організаціям і спільна робота з ними з комуністичного виховання молоді;

- організація й проведення позакласної роботи з учнями; суспільно-корисна робота з ними;

- робота з батьками учнів [2, с. 9]. 
Мета діяльності класного керівника (зокрема, вчителя початкових класів) полягала, перш за все, в урізноманітненні занять зі школярами (суспільна праця, ігри, корисні заняття, спортивні заняття, художня творчість). До зазначених видів діяльності варто додати бесіди на етико-моральні теми, політінформацію, організацію читацьких вечорів, конференцій, екскурсій, походів, відвідування театрів та кінотеатрів тощо.

Крім освітньої діяльності з учнями безпосередньо в школі, вчитель початкової шкоди мав обов'язково проводити роботу з батьківською громадськістю та активно співпрацювати з нею. У післявоєнний час багато дітей залишилося сиротами або батьки багато працювали та не мали змоги приділяти достатньої уваги власним дітям, що створювало певну психолого-педагогічну проблему в оволодіванні знаннями.

Відповідно до посадових обов' язків, вчитель початкової шкоди мав спостерігати за учнями не лише в класі, а й поза його межами під час перерв, заходів, екскурсій, при виконанні доручень, у колі друзів та родини.

У посібнику для вчителів початкової школи тих років наводиться приклад практичного досвіду організації роботи з батьками. Учень С. був дуже слабкий в арифметиці. В класі С. завжди був пасивним, нетовариським та не життерадісним. Вчителька часто замислювалася над причиною його поганої успішності. Одного разу, в бесіді з С., вона дізналася, що хлопець абсолютно самотній: батько загинув на фронті, мати не цікавиться ним, друзів немає. Вчителька почала приходити до матері хлопця й багато 3 нею розмовляла $з$ метою наближення їі до сина. Вона досягла того, що мати стала більш уважнішою до хлопця. Це помітно вплинуло на С., він став активнішим на уроках, почав цікавитися арифметикою та просити давати йому додаткові задачі. Увага з боку вчительки та матері змінила ставлення хлопця до навчання [3, с. 129].

Звісно така робота забирала багато сил та виснажувала вчителя, зменшувала кількість вільного часу на відпочинок.

Багато сил вимагав від учителя й початок нового навчального року. Це надзвичайно відповідальний час, оскільки саме в цей період закладається фундамент міжособистісних відносин між учнями та класним керівником [3, с. 19].

Серед основних видів взаємодії вчителя з класом виділяли такі:

- принципове ставлення до праці, навчання та здорової критики;

- зрощування любові не лише до навчального процесу, але й до виробничої, розумової та фізичної діяльності;

- допомога слабо встигаючим учням у навчанні шляхом спостереження за їхніми

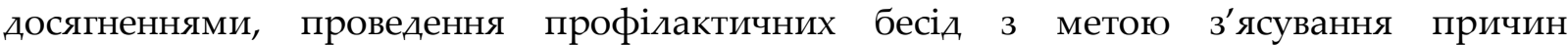
відставання, вивчення їхніх побутових умов;

- активна співпраця 3 піонерськими та комсомодьськими організаціями [3, с. 54].

Вчителі початкових класів привчали дітей 3 молодшого шкільного віку до колективізму в усьому: від колективної суспільно-корисної праці, до колективного вирішення особистісних проблем 3 винесенням на широкий загал, 3 метою допомоги. До таких видів діяльності активно залучалися вчителі, дирекція шкіл, батьківська громадськість, піонервожаті та ін.

У 50-х рр. ХХ ст. виховна складова діяльності вчителя початкових класів включала в себе багато напрямів, серед яких: фізичне, художне, трудове виховання. Окремим напрямом виділялось виховання свідомої дисципліни та навичок культурної поведінки, провідною метою якого було привчання учнів якомога краще виконувати вимоги, накази, розпорядження задля виконання власного зобов'язання 3 особистої ініціативи [5, с. 184]. Дисциплінування учнів відбувадось за допомогою методів стимулювання, заохочення та покарання.

Одним із провідних напрямів роботи з учнівською мододдю стало фізичне виховання. Вчитель початкових класів мав не лише дуже добре знати анатомофізіологічні особдивості розвитку учнів мододшого шкільного віку, а й проводити спільно з учителем фізичної культури оздоровчі заходи. У той час у посібнику

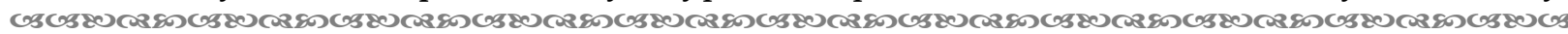
277 
для вчителів початкової школи наводилися рекомендації щодо поєднання виконання фізичних вправ із повітряними та сонячними ваннами, а також 3 водними процедурами 3 метою загартування дитячого організму [5, с. 208].

Окрім загартування, вчитель мав оперувати знаннями щодо організації правильного режиму дня та харчування мододших школярів. Зокрема, педагогам пропонувалося домогтися того, щоб учні завжди снідали в один й той самий час у школі, проводити в теплу пору року уроки та заняття на повітрі або при відкритому вікні, а також популяризувати серед школярів навички, пов'язані із виконанням режимних моментів (рано лягати та вставати, на перервах виходити на вулицю, провітрювати приміщення тощо).

Вчителі початкової школи мали обов'язково враховувати індивідуальні особливості учнів, а особливо з ослабленим здоров'ям. До таких категорій належали учні із загальмованістю у розвитку, нервово збуджені, діти із закритою формою туберкульозу, ревматики та діти із поганим зором. Мережа інкдюзивних освітніх закладів не була настільки поширена, щоб учні з особливими освітніми потребами навчадися у відповідних умовах, тому вчителі мади виконувати свою роботу із урахуванням анамнезу захворювання дитини. Так, у процесі роботи 3 дітьми із різними нозологіями вчитель був повинен:

- з'ясувати у лікаря стан зору та слуху учнів свого класу та посадити туговухих ближче до свого столу, слабозорих дітей - на перші парти, ближче до вікна. Роз' яснювати учням необхідність носіння окулярів, якщо їх прописав лікар;

- усіляко допомагати ослабленим учням, які перенесли гострі інфекційні захворювання, не завантажувати їх суспільними завданнями та дорученнями;

- дітей із порушеннями мовлення направляти до дікаря-спеціаліста. Розмовляти 3 такими дітьми чітко та повільно, не квапити 3 відповідями, допомагати у вимові складних слів. Не дозволяти іншим дітям дражнити таких учнів;

- оберігати легко збудливих дітей від активностей, які можуть призвести до ще більшого збудження нервової системи. Із млявими дітьми застосовувати додаткові прийоми для активізації та підтримки їхнього інтересу до навчадьного процесу (спеціальні завдання тощо) [5, с. 217].

Висновки. Отже, впродовж 1950-х рр. відбувалась активна відбудова країни в післявоєнний період. Відновлення важкої та легкої промисловості потребувало багато ресурсів та робочої сили в найкоротші терміни. Досягти цього можна було шляхом об'єднання громади єдиною спільною ідеєю будувати комунізм та активно реалізувати принципи радянської ідеології. Для виконання такого плану країні необхідні були здорові та висококваліфіковані спеціалісти, які знають свою справу і належним чином виконують накази та розпорядження. Така підготовка розпочиналась із початкової школи, а отже, на вчителів початкових класів покладалась надзвичайна відповідадьність за виховання майбутніх будівників комунізму.

Порушена у статті проблема виховної діяльності вчителів початкових класів в 50-х рр. XX ст. багатоаспектна і потребуе подальшої наукової розробки.

\section{Список використаних джерел:}

1. Бахмат Н. В. Теоретичні і методичні засади педагогічної підготовки вчителів початкової школи в умовах інформаційно-освітнього середовища вищого навчального закладу: дис. ... д-ра пед. наук: 13.00.04 / Нац. пед. ун-т ім. М. П. Драгоманова. Київ, 2017. 510 с.

2. Болдырев Н. И. Классный руководитель: пособие для классных руководителей средних школ. 2-е изд. Москва: Академия педагогических наук РСФСР, 1955. 351 с.

3. Данилов М. А. Первая учебная четверть в школе. 2-е изд. Москва: Академия педагогических наук РСФСР, 1955. 72 с.

4. Кірдан О. А. Виховні функції класного керівника в навчальних закладах України (середина XIX - початок XX століття): автореф. дис. ... канд. пед. наук: 13.00.01 / Уманський держ. пед. ун-т ім. П. Тичини, Київ, 2002. 19 с. 
5. Мельников М. А. Начальная школа: настольная книга учителя. Москва: Академия педагогических наук РСФСР, 1950. 944 с.

6. Нова українська школа: основи Стандарту освіти / Д. Гриневич, В. Бриндза, Н. Дементієвська та ін. Аьвів, 2016. 64 с.

7. Шквир О. А. Теоретичні і методичні засади ступеневої підготовки майбутніх учителів початкової школи до проведення педагогічних досліджень: дис. ... д-ра пед. наук: 13.00.04 / Житомирський держ. пед. ун-т ім. І. Франка. Житомир, 2018. 572 с.

8. Шугай Я. М. Розвиток початкової освіти у вітчизняній педагогічній теорії і практиці (1932 1958 рр.): дис. ... канд. пед. наук: 13.00.01 / Тернопільський нац. пед. ун-т ім. В. Гнатюка. Тернопіль, 2019. 314 с.

\section{Reference:}

1. Bakhmat, N. V. (2017). Teoretychni i metodychni zasady pedahohichnoi pidhotovky vchyteliv pochatkovoi shkoly $\mathrm{v}$ umovakh informatsiino-osvitnoho seredovyshcha vyshchoho navchalnoho zakladu [Theoretical and methodological foundations of pedagogical training of elementary school teachers in the conditions of the information and educational environment of a higher educational institution]. (Doctor's thesis). National Pedagogical Dragomanov University. Kyiv [in Ukrainian].

2. Boldyrev, N. I. (1955). Klassnyi rukovoditel: posobie dlia klassnykh rukovoditelei srednikh shkol [Class teacher: a guide for class teachers of secondary schools]. Moskva: Akademiia pedagogicheskikh nauk RSFSR [in Russian].

3. Danilov, M. A. (1955). Pervaia uchebnaia chetvert $\mathrm{v}$ shkole [The first academic term at school]. Moskva: Akademiia pedagogicheskikh nauk RSFSR [in Russian].

4. Kirdan, O. L. (2002). Vykhovni funktsii klasnoho kerivnyka $v$ navchalnykh zakladakh Ukrainy (seredyna XIX KhIKh - pochatok XX stolittia) [Educational functions of the class teacher in educational institutions of Ukraine (the middle of the XIX century - the beginning of the XX century)]. (Extended abstract of candidate's thesis). Pavel Tychyna Uman State Pedagogical University. Kyiv [in Ukrainian].

5. Melnykov, M. A. (1950). Nachalnaia shkola: nastolnaia knyha uchytelia [Elementary school: a teacher's handbook]. Moskva: Akademyia pedahohycheskykh nauk RSFSR [in Russian].

6. Hrynevych, L., Bryndza, V., \& Dementiievska, N. (2016). Nova ukrainska shkola: osnovy Standartu osvity [New Ukrainian school: bases of the Standard of education]. Lviv [in Ukrainian].

7. Shkvyr, O. L. (2018). Teoretychni i metodychni zasady stupenevoi pidhotovky maibutnikh uchyteliv pochatkovoi shkoly do provedennia pedahohichnykh doslidzhen [Theoretical and methodical principles of stage preparation of the future primary school teachers for conducting pedagogical researches]. (Doctor's thesis). Zhytomyr Ivan Franko State University. Zhytomyr [in Ukrainian].

8. Shuhai, Ya. M. (2019). Rozvytok pochatkovoi osvity u vitchyznianii pedahohichnii teorii i praktytsi (1932-1958 rr.) [Development of primary education in the domestic pedagogical theory and practice (1932-1958)]. (Candidate's thesis). Ternopil Volodymyr Hnatiuk National Pedagogical University. Ternopil [in Ukrainian].

Shuhai Ya. M., orcid.org/0000-0002-2325-6303 Lupinovych S. M., orcid.org/0000-0002-6185-470X EDUCATIONAL ACTIVITIES OF ELEMENTARY SCHOOL TEACHER (50'S OF THE XXTH CENTURY)

The article is devoted to the actual topic of modern education, namely, the educational activities of elementary school in the 50's of the XXth century.

The main vectors of the development of education in Ukraine, in particular in the elementary schools, are analyzed by studying the original sources of the outlined time period. It has been established that education in a global sense and local class teachers were one of the important levers of human consciousness control and the formation of the worldview of the future builders of communism in the country. It was determined that one of the conditions for the transition from socialism to communism of the researched period is the cultural growth of society and the provision 
of all community members with the comprehensive development of their mental and physical abilities. However, along with mastering the foundations of the sciences, the state faced the task of providing youth with polytechnic training and educating them in the spirit of communist morality, developing their physical and artistic inclinations.

The main directions of the educational activities of the class teacher with elementary scholars as physical, aesthetic, labor education, are revealed. Work with the parental collective and cooperation with the Komsomol and pioneer organizations have become widespread. The active involvement of scholars with special educational needs in the educational process and the obligatory consideration of the individual characteristics of scholars at the planning of educational activities is noted.

It was concluded that the tension and responsibility in the work of the class teacher was extremely high. Indeed, in addition to the main activity at school, the class teacher must provide and diversify activities with scholars outside the classroom, either. This pace of work significantly reduced the effectiveness of the teacher's work and emotional involvement in educational activities.

Key words: class teacher, elementary school, education trends, post-war period, scholar's organization, work with parents, education trends.

Дата надходження статті: 22.122020 p. Рецензент: доктор педагогічних наук, професор Борисов В. В. 